\title{
Handbook of Florida Water Regulation: Soil and Water Conservation Districts ${ }^{1}$
}

\author{
Michael T. Olexa, Tatiana Borisova, and Jarrett Davis²
}

\section{Preface}

This handbook is designed to provide an accurate, current, and authoritative summary of the principal federal and state (Florida) laws that directly or indirectly relate to agriculture. This handbook provides a basic overview of the many rights and responsibilities that farmers and farmland owners have under both federal and state laws as well as the appropriate contact information to obtain more detailed information. However, the reader should be aware that because the laws, administrative rulings, and court decisions on which this handbook is based are subject to constant revision, portions of this publication could become outdated at any time. Several details of cited laws are also left out due to space limitations.

This handbook is distributed with the understanding that the authors are not engaged in rendering legal or other professional advice, and the information contained herein should not be regarded as a substitute for professional advice. This handbook is not all inclusive in providing information to achieve compliance with the federal and state laws and regulations governing water protection. For these reasons, the use of these materials by any person constitutes an agreement to hold harmless the authors, the UF/IFAS Center for Agricultural and Natural Resource Law, the Florida Cooperative Extension Service, the Institute of Food and Agricultural Sciences, and the University of Florida for any liability claims, damages, or expenses that may be incurred by any person as a result of reference to or reliance on the information contained in this handbook.

\section{Soil and Water Conservation Districts: Overview}

Previous chapters of this Handbook of Florida Water Regulations discuss state agencies involved in water resource management, such as the Florida Department of Environmental Protection (FE593), Florida Water Management Districts (FE594), Florida Fish and Wildlife Conservation Commission (FE595), Florida Department of Agriculture and Consumer Services (FE596), and Florida Department of Health (FE597). For water resource issues in agricultural areas, the discussion of agencies working on water resource management would be incomplete without Florida Soil and Water Conservation Districts.

Florida's Soil and Water Conservation Districts (SWCD) were established in 1937, under Chapter 582, Florida Statutes, to oversee the state's natural resource management programs (https://afcd.us). Florida's SWCD is part of the nationwide system that was established in the 1930s in response to the Dust Bowl environmental crisis, when dust storms related to droughts and soil erosion were numerous and severe, especially in the southern Great Plains. Today, over 3,000 SWCDs exist nationwide.

1. This is EDIS document FE1017, a publication of the Food and Resource Economics Department, UF/IFAS Extension. Published December 2017. Please visit the EDIS website at http://edis.ifas.ufl.edu.

2. Michael T. Olexa, professor, Food and Resource Economics Department, and director, UF/IFAS Center for Agricultural and Natural Resource Law, UF/ IFAS Extension, Gainesville, FL, and member of The Florida Bar. Tatiana Borisova, associate professor, Food and Resource Economics Department, UF/ IFAS Extension, Gainesville, FL. Jarrett Davis, student Levin College of Law, University of Florida, Gainesville, FL.

The Institute of Food and Agricultural Sciences (IFAS) is an Equal Opportunity Institution authorized to provide research, educational information and other services

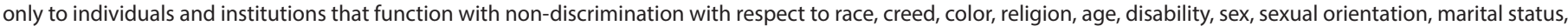

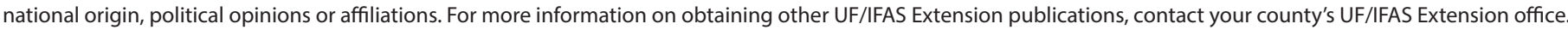
U.S. Department of Agriculture, UF/IFAS Extension Service, University of Florida, IFAS, Florida A \& M University Cooperative Extension Program, and Boards of County Commissioners Cooperating. Nick T. Place, dean for UF/IFAS Extension. 


\section{Purpose of SWCD}

The Florida legislature created soil and water conservation districts "to provide assistance, guidance, and education to landowners, land occupiers, the agricultural industry, and the general public in implementing land and water resource protection practices." (Chapter 582, Florida Statutes, Section 582.02). The overall goal of creating SWCDs was to promote the efficient use of soil and water resources by protecting water quality and preventing floodwater and sediment damage.

SWCDs are involved in such activities as implementing agricultural practices to protect soils, water, air, and wildlife; protect and restore water resources; work with developers to protect natural resources during construction stages; and implement outreach activities. Specifically, SWCDs may conduct research, teach best management practices for soil and water conservation, and develop comprehensive plans for soil erosion control and flood prevention.

Under the authority of the Soil Conservation Act, SWCDs identify areas within each district that require further conservation measures. SWCDs may adopt land-use regulations that can require certain agricultural practices such as contour cultivation, strip cropping, and the planting of erosion-preventative vegetation. However, SWCDs do not have the power to enforce these regulations.

See https://afcd.us/florida-swcd-districts/ for an interactive map of all of Florida's SWCDs.

\section{Structure of SWCD}

Florida has fifty-eight SWCDs, each of which is self-governed by a board composed of locally elected supervisors. Candidates for the SWCD boards are elected in a general election to a four-year term. Vacancies are filled by appointment by the remaining supervisors until the next regular election. Supervisors conduct studies, surveys, and research relating to soil and water. Also, they conduct projects for conservation, protection, and restoration of soil and water sources, including agricultural best management practice demonstration projects (Chapter 582, Florida Statutes, Section 582.20).

\section{Partnerships with SWCD}

SWCDs work together with federal, state, and local agencies to provide assistance and guidance to the agricultural landowners and the public. They serve as a liaison between landowners and regulatory agencies. SWCDs obtain funding from state and federal cost-share programs which can be used for environmental practices, emergency watershed projects, and federal disaster relief.

At the federal level, the Natural Resources Conservation Service (NRCS), a branch of the United States Department of Agriculture, works with the SWCD boards to offer farmers assistance through such programs as the Conservation Technical Assistance Program in conserving and maintaining their soil, water, and other natural resources against such damages as topsoil and water erosion of their fields. It also helps farmers limit water contamination and water misuse on their farms. All NRCS measures are voluntary and are often referred to as best management practices. In addition to NRCS, SWCDs regularly partner with other agencies, such as the Florida Department of Agriculture and Consumer Services.

\section{Associations of Conservation Districts}

The Association of Florida Conservation Districts and the National Association of Conservation Districts assist and coordinate SWCDs with natural resource endeavors. These non-profit agencies act as a unified voice and liaison to represent Districts to State and Federal Agencies and to outside organization.

\section{Sources}

Chapter 528, Florida Statutes

Association of Florida Conservation Districts

National Association of Conservation Districts

\section{Acknowledgments}

The authors are indebted to the personnel of both state and federal agencies who provided their time and advice in the preparation of this handbook. We acknowledge Carol Fountain and Susan Gildersleeve at the University of Florida for their assistance in editing this handbook. We also acknowledge funding received for updating this publication from the 2016 Wells Fargo Extension Professional Award and Program Enhancement Grant (Principal Investigator is Tatiana Borisova). 